\title{
The Effects of Customers' Perceived Relational Benefits on The Customer Perception of Service Innovation at Service Centers for IT Products: The Mediating Role of Customer Participation
}

\author{
Wujin Chu and MinjeongKang \\ College of Business Administration ,Seoul National University, Republic of Korea
}

Correspondence should be addressed to: MinjeongKang; 7minjeong@hanmail.net

Received date: 17 December 2013; Accepted date: 30 January 2014; Published date: 27 November 2014

Academic Editor: Jung Wan Lee

Copyright (C) 2014. Wujin Chu and MinjeongKang. Distributed under Creative Commons CC-BY 3.0

\begin{abstract}
This study examines the relationships between customers' perceived functional (social) benefits from service providers and customers' perception of service innovation. It also assesses the mediation effects of their participation on their perception of service innovation. Focusing on service centers for ITproducts, structural equation modeling is used to test the hypotheses with data collected from 116 university students in South Korea. The results demonstrate that customers' perceived functional benefits from service providers and their perceived social benefits significantly and positively influence their perception of service innovationat service centers for IT products. Additionally, customers' participation partially mediates the relationships between their perceived functional (or social) benefits, and their perception of service innovationat service centers for IT products. The theoretical and managerial implications of these findings are also discussed.These findings may help in identifying factors that enhance customers'perception of service innovation.
\end{abstract}

Keywords: Perceived Functional Value, Perceived Social Value, Customers' Participation, Customers' Perception of Service Innovation

\section{Introduction}

Today's service industry is evolving rapidly because of advances such as the Internet and e-commerce, and the increasing demands of discerning customers (Lovelock et al., 2001). This industry has also become increasingly important, and the dependence of existing manufacturing industries on service industries has increased as well (Xin et al.,

Cite this Article as: Wujin Chu and MinjeongKang (2014), " The Effects of Customers' Perceived Relational Benefits on The Customer Perception of Service Innovation at Service Centers for IT Products: The Mediating Role of Customer Participation ", Journal of Administrative Sciences and Technology , Vol 2014 (2014), Article ID 130915, DOI: 10.5171/2014.130915 
2006). Further, the share of service industries in the world economy has gradually increased(Dotzel et al., 2013). Overall, companies must innovate their services, because of the growing dependence of businesses on customer satisfaction, increased competition, fast-changing technology, increased levels of information availability, and the changing legal environment (Anatan and Radhy, 2007; Dotzel et al., 2013).

Studies on service innovation are not as frequent as those on innovations in manufacturing businesses (den Hertog, 2000). Only a few research papers have studied factors affecting service innovation, which is defined as a new or improved intangible offering affecting a company's operations or performance of activities for the benefit of customers (Dotzel et al., 2013).Service innovations are influenced by both customer participation and customer service experience, which together play a role in value creation and lead to higher performance in service productivity and various other processes (den Hertog, 2000).

So far, although customers have been the center of service innovations, no studies have been conducted on customers'relational benefits as variables potentially affecting service innovation. The objective of this study is to examine the effect of customers'relational benefits on service innovation,focusing on customers who use service centers for IT products. In this research, customers'relational benefits are categorized as functional and social; the direct effects these variables have on service innovation are examined. Further, how customer participation in service serves as an intermediary in the relationship between customer benefits and service innovation is also investigated.

\section{Theoretical Framework and Hypotheses}

\section{Service Innovation}

The idea of service innovation introduced by
Schumpeter (1934), was initially discussed on the basis of product and process innovation. A service innovation is a new or improved intangible benefit offered and provided by a company to the company's customers (Dotzel et al., 2013).Toivonen and Tuominen(2009) defined the term as such: the implementation of a new service or a renewed existing service that benefits the organization that has developed it; the benefit is usually derived from the added value provided by the new or improved service to customers. Therefore, a service

innovation can be defined as the implementation of a new service, or the renewal of an existing service which provides benefit to the implementing organization derived from the added value that the innovation provides to customers. Thus, service innovations encompass new, improved, andmore efficient services along with the creative effort necessary to develop them (Toivonen and Tuominen, 2009; Schwarz et al. 2012).

Xin et al. (2006) divided service innovation success factors into internal and external ones. The internal factors included strategy, resources, and culture. Strategy refers to the clear goal setting, the support of top management, and smooth communication; the notion of resources pertains to available knowledge and skills; and culture refers to the support of senior management for innovation and cooperation. The external factors included customer involvement, customer experience, and networking between service companies (Xin et al., 2006).They encompass the complementarity of current services to existing services and customers' perceived customer benefits(Storeyand Easingwood, 1993; van Riel et al., 2004).

\section{Customers' Relational Benefit}

Relational benefits are benefits arising from a long-term relationship between a company or a service provider and its customers; these involve more than just core services (Gwinner et al. 1998; Su et al, 2009). Morgan and Hunt (1994) defined relationship 
marketing as 'marketing activities directed toward establishing, developing, and maintaining successful relational exchanges.' Through this, a company can enhance performance and make a firm relationship with its customers (Morgan and Hunt, 1994). A good relationship with customers is vital to marketing as it positively affects customer satisfaction, loyalty, word of mouth publicity and purchase decisions. Despite this, the effects of customer benefits have not garnered empirical attention (Reynolds and Beatty, 1999).

Gwinner et al. (1998), too, emphasized the importance of customers' relational benefits in service industries. They defined customer's relational benefits, in terms of customer relationships, as services exceeding core service performance, obtained by customers through a long-term relationship. Thus, these types of benefits can also be achieved when a service provider and its customers share a good relationship (Gwinner et al., 1998).Palmatier et al. (2006) pointed out that customers concentrate on relational exchanges, while companies provide relational benefits for customer retention (Morgan and Hunt 1994).

\section{Effects of Customers' Relational Benefits on Perceived Service Innovation}

Hipp and Grupp (2005) stated that the improved service innovation is achieved when the customer value is created through the provision of services, while service innovation focuses on creating value through service relationships between a company and its customers (Vargo and Lusch, 2004; Liu and Chen, 2007). Consumers choose products and services based on desired benefits (Reynolds and Gutman, 1984) and pursue benefits from interpersonal relationships (McAdams et al., 1998).

According to Gwinner et al. (1998), relational benefits can be divided into confidence, social, and special treatment benefits or into functional and social benefits (Beatty et al., 1996; Reynolds and Beatty, 1999). Functional benefits include time saving, convenience, and improved purchase decisions, whereas social benefits are defined as customer benefits gained through positive relationships with sellers or service providers (Sweeney and Webb, 2007).

Reynolds and Beatty (1999) mentioned that social and functional benefits are important dimensions of relational benefits. Thus, these two types of benefits are considered in the current study: functional and social. Functional benefits focus on saving time and increasing convenience for customers, while social relational benefits arise from face-toface interactions between customer and service provider (Beatty et al. 1996; Su et al., 2009). Functional relational benefits are related to value and customers perceive them over the duration of their interaction and relationship with the service provider. They can be weighed against cost increase (Jackson, 1985; Beatty et al., 1996). The term refers to the social standing that customers obtain through interaction with a company and its employees; these include concepts such as friendship, fraternization, and personal recognition (Su et al, 2009). A study has shown that the greater the social and functional benefits sensed by a customer, the higher is the customer's satisfaction with his/her sales person (Reynolds and Beatty, 1999). Thus, both these benefits are important factors for building satisfying relationships with customers.

Service innovations will take place more smoothly when effective attachment, intimacy, and social support are present (Price and Amould, 1999). Service innovation could then be considered the creation of new ways to meet unmet customer demands(Singhi and Agarwal, 2011). Based on the above reasoning, this research hypothesizes that the two types of customers'perceived relational benefits may have a positive effects on customers' perception of service innovation.

H1: Customers' perceived functional benefits from service providers have a positive influence on customers' perception of service innovationat service centers for IT products. 
H2: Customers' perceived social benefits from service providers have a positive influence on customers' perception of service innovationat service centers for IT products.

\section{Mediating Role of Customer Participation between Perceived Relational Benefits and Customer Perception of Service Innovation}

With advances in technology and changes in customers' shopping patterns and experiences, the active participation of consumers is required (Prahalad and Ranaswarny, 2000). Silpakit and Fisk (1985) specify customer participation as 'the degree of consumers' effort and involvement, both mental and physical, necessary to participate in production and delivery of services. Similarly, Rodie and Kleine (2000) interpret customer participation as 'a behavioral concept that refers to the actions and resources supplied by customers for service production and/or delivery,'emphasizing the fact that customer participation is essential in service delivery.

The characteristics of customer service include non-separability, non-visibility, volatility, and heterogeneity (Carman andLangeard, 1980). Customer interaction can also be considered a characteristic (Menor and Sampson, 2002). Service innovation demands an interaction between service providers and customers (Alam, 2002; Liu and Chen, 2007) and is in fact developed through this close interaction. It is developed in business networks rather than in labs (Dotzel et al., 2013), and customer participation performs a critical role in service innovation(Kuusisto and Riepula, 2011; Wu, 2011), because it reduces time, decreases costs, and improves perceived service value (Alam, 2002). Service innovation can be achieved in the course of resolving problems that occur during customer service activities (Edvardssonet al., 2004). Therefore, the customer's role in the service production and delivery process can be described as a customer participatory action.
On the other hand, the efficiency of relationship marketing depends more on the degree of customer participation than on the efforts of companies (Hakansson and Ford, 2002). Customer relational benefits may be improved via commitment to good relationships with customers (Dimitriadis, 2010). Dabholka (1990) reported that customer participation enhances the perception of service quality and customer satisfaction. According to Yoon et al. (2004), customer participation is the leading factor affecting the employee effortthrough customer participation, employees work harder to meet customers' needs, because relationships are formed in the course of service interaction.

Customer participation can form positive relationships through involvement with service providers (McLaughlin and Paton, 2008). However, only a few studies have emphasized customer participation as an important factor in innovation (de Brentani and Cooper, 1992). Customer participation will only be achieved if they expect to gain benefits from the relationship (Chan et al, 2010). In service innovation, customer participation is more important than product innovation (Sundbo, 1997).

Based on this theoretical foundation, the mediating role of customer participation is examined in processes where service relational benefits affect customers' perception of service innovation.

H3: Customers' perceived functional benefits from service providers have a positive influence on customers' participation.

H4: Customers' perceived social benefits from service providers have a positive influence on customers' participation.

H5: Customers' participation from service providers has a positive influence on customers' perception of service innovationat service centers for IT products. 
H6: Customers' participation mediates the relationship between perceived functional benefits, and customers' perception of service innovationat service centers for IT Products.
H7: Customers' participation mediates the relationship between perceived social benefits, and customers'perception of service innovationat service centers for IT products.

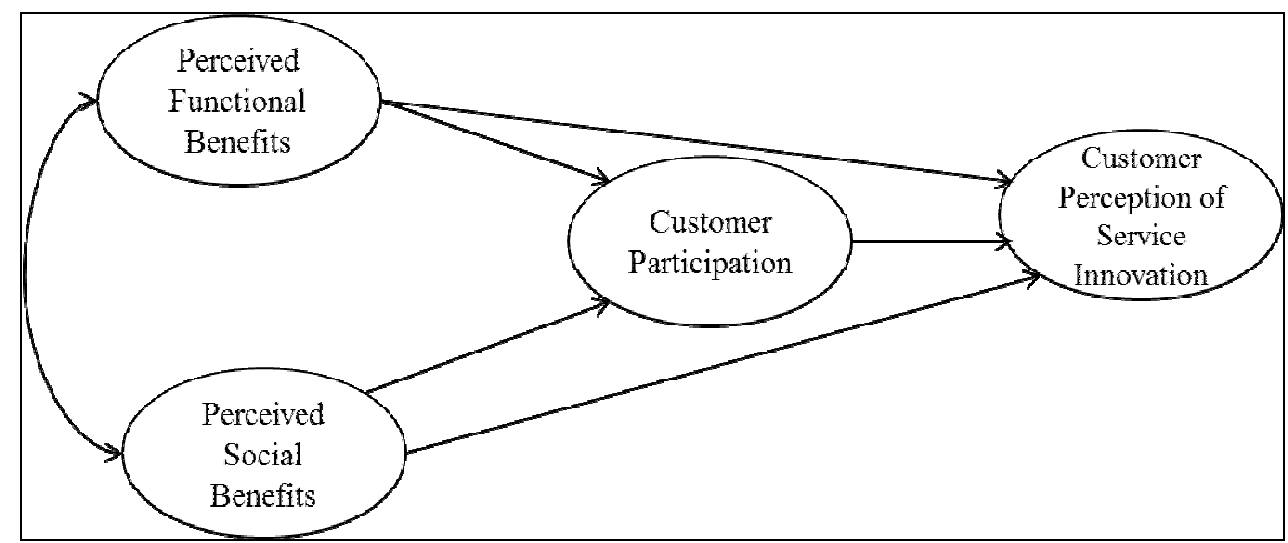

Figure 1: Perceived Relational Benfits, Customers' Participation and Customers' Perception of Service Innovation Structural Model

\section{Methodology}

\section{Data Collection}

The subjects for the study were university students who possess computers, digital cameras and cell phones, who actively use electronic products and services,and who use customer service centers for IT products more than once a year. Through survey, the data were collected. A total of 130 respondents were surveyed and 116 respondents were selected for the study, excluding 14 students who did truthfully answer the survey questions. Their ages are between 22 and 32, and $89 \%$ of them are in their 20s. All the respondents are currently attending university. The items brought to the service centers are cell phones, computers, and digital cameras, in that order of frequency.

\section{Measurement}

The data presented in this study were a result of evaluation by the subjects who answered all the questionnaire questions using a 7point likert scale ranging from 1 to 7 . All the research papers were selected from preceding studies on marketing or consumer behaviors. Based on Baker and Sinkula(1999) and Kim (2012) customers' perception of service innovation was defined in this study as customers' perception of new developments, based on changes in customer behavior made to improve customer satisfaction. The measurement items include four items developed by Baker and Sinkula(1999) and Kim (2012). The functional and social benefit aspects of relational benefits were used according to the questionnaire used in the study of Jin et al. (2010). Relationships with 'sales associates' in the paper of Reynolds and Beatty (1999) and with 'members of online community' in the paper of Jin et al. (2010)to with 'service providers' were replaced in this paper. When looking at customers' participation, four questionnaires were constructed based on the papers of Bettencourt(1997) and Eisingerich and Bell(2006). Measurement Items were shown in Table 2. Reliability estimates for the scales is acceptable because all factor composite reliabilities'Cronbach alpha coefficients are over 0.70 , which is the

Wujin Chu and MinjeongKang (2014), Journal of Administrative Sciences and Technology, DOI: $10.5171 / 2014.130915$ 
recommended value by Hairetals. (1998) (perceived functional benefits'Cronbah alpha $=.85$, perceived social benefits'Cronbah alpha $=.85$, customers' participation's Cronbah alpha $=.89$, customers' perception of service innovation's Cronbah alpha $=.86$ ). Table 1 depicts the descriptive statistics and correlations of all variables.

Table 1: Descriptive Statistics and Correlations of All Variables

\begin{tabular}{|l|l|l|l|l|l|l|}
\hline & Mean & SD & 1 & 2 & 3 & 4 \\
\hline Perceived functional benefits & 4.52 & 1.07 & 1.00 & & & \\
\hline Perceived social benefits & 3.80 & 1.23 & $0.57^{* *}$ & 1.00 & & \\
\hline Customers' participation & 5.23 & .88 & $0.60^{* *}$ & $0.56^{* *}$ & 1.00 & \\
\hline Customers' perception of service innovation & 4.79 & .92 & $0.57^{* *}$ & $0.56^{* *}$ & $0.59^{* *}$ & 1.00 \\
\hline
\end{tabular}

SD standard deviation ${ }^{* *}$ All correlations are significant at the $0.01 \%$ level, using a two-tailed t-test.

\section{Results}

\section{Confirmatory Factor Analysis}

Confirmatory factor analysis (CFA) was conducted to measure the properties of the scale items. CFA results, produced a good fit to the data indicating the overall fit of the measurement model, was adequate, $X^{2}=$ $311.60(d f=84, p<.001), \mathrm{X}^{2} / \mathrm{df}=1.57, \mathrm{RMSEA}$ $=0.07, \mathrm{CFI}=0.96, \mathrm{IFI}=0.95, \mathrm{TLI}=0.95$. The value of CFI, IFI, TLI were higher than the 0.9 threshhold value (Byrne, 1998). An RMSEA value between .05-.08 also showed a satisfactory model fit (Turner andReisinger, 2001). Table 2 describes the specific measurement items, standardized factor loading values, t-values and AVE values.The factor loading values were significantly above
0.50 threshold (Fornell and Larcker, 1981). As depicted in Table 2, the average variance extracted (AVE) was greater than the variance unexplained and over .50 threshhold (Bagozziand Yi, 1988; Fornell and Larcker, 1981). Factor composite reliability is equal to or higher than 0.60 (Fornell and Larcker, 1981). Table 2 reports the results of CFAs. It showed strong convergent validity for the measurement scale. The discriminant validity AVE values for each proposed concept exceed the squared correlations estimates (Fornell and Larcker, 1981; Hair et al., 2006). As shown in table 1 and 2, the discriminant validity was satisfied as AVE value of all variables exceed the squared correlations of any pairs of variables.

Table 2 : Results of Confirmatory Factor Analysis

\begin{tabular}{|l|l|l|l|l|}
\hline Constructs & $\begin{array}{l}\text { Factor } \\
\text { loading }\end{array}$ & S.E. & CR & AVE \\
\hline Perceived Functional Benefits & & & 0.88 & 0.65 \\
\hline $\begin{array}{l}\text { I value the convenience service providers at service centers for IT } \\
\text { products provides me. }\end{array}$ & .82 & & \\
\hline I value the time service providers at service centers for IT & .95 & .10 & & \\
\hline
\end{tabular}

Wujin Chu and MinjeongKang (2014), Journal of Administrative Sciences and Technology, DOI: $10.5171 / 2014.130915$ 


\begin{tabular}{|c|c|c|c|c|}
\hline ducts: & & & & \\
\hline $\begin{array}{l}\text { I value the advice service providers at service centers for IT } \\
\text { productsprovides me. }\end{array}$ & .75 & .11 & & \\
\hline $\begin{array}{l}\text { I make better purchase decisioins because of service providers at } \\
\text { service centers for IT products. }\end{array}$ & .57 & .13 & & \\
\hline Perceived Social Benefits & & & 0.83 & 0.62 \\
\hline $\begin{array}{l}\text { Friendship with service providersat service centers for IT products is } \\
\text { valuable to me. }\end{array}$ & .86 & & & \\
\hline $\begin{array}{l}\text { I enjoy spending time with service providersat service centers for IT } \\
\text { products. }\end{array}$ & .79 & .11 & & \\
\hline $\begin{array}{l}\text { I value the intimate relationship with service providersat service } \\
\text { centers for IT products. }\end{array}$ & .78 & .09 & & \\
\hline $\begin{array}{l}\text { Customers' Perception of Service Innovation at Service Centers for } \\
\text { IT Products. }\end{array}$ & & & 0.87 & 0.64 \\
\hline $\begin{array}{l}\text { Service centers for IT products redefine the concept of their products } \\
\text { or services whenever there are changes in customers behavior. }\end{array}$ & .70 & & & \\
\hline $\begin{array}{l}\text { Service centers for IT products redefine the concept of their products } \\
\text { or services to accommodate changes in customers behavior. }\end{array}$ & .87 & .15 & & \\
\hline $\begin{array}{l}\text { Service centers for IT products always try to improve their } \\
\text { capabilities necessary to provide their products or service. }\end{array}$ & .87 & .14 & & \\
\hline $\begin{array}{l}\text { Service centers for IT products always try to observe and respond to } \\
\text { changes in customer behavior. }\end{array}$ & .71 & .15 & & \\
\hline Customers' participation & & & 0.88 & 0.66 \\
\hline $\begin{array}{l}\text { I let service centers for IT products learn of ways so that they can } \\
\text { better serve my needs. }\end{array}$ & .83 & & & \\
\hline $\begin{array}{l}\text { I make constructive suggestions to service centers for IT products on } \\
\text { how to improve the service. }\end{array}$ & .96 & .08 & & \\
\hline $\begin{array}{l}\text { When I experience a problem at service centers for IT products, I } \\
\text { inform them so they can improve service quality. }\end{array}$ & .79 & .10 & & \\
\hline $\begin{array}{l}\text { If service centers for IT products give me good service, I let them } \\
\text { know it. }\end{array}$ & .53 & .12 & & \\
\hline
\end{tabular}

\section{Structural Equation Modeling (SEM)}

In order to verify the relationship between the Hypotheses and variables, AMOS 18.0 was used to test SEM. Table 3 shows the results of the structural model displaying inter relationships between each construction. The overall model fit is higher than the baseline score in the previous studies indicating a satisfactory fit. As shown in Table 3, the results support all the main hypotheses.

Table 3 shows the standardized regression weights. As shown in Table 3, customers'perceived function benefits from service providers exerted a significant effect on customers' perception of service innovation $(\beta=0.29, \mathrm{p}<0.05)$, which was found to be consistent with H1. In accordance with H2, Customers' perceived social benefit from service providers also revealed a significant impact on customers' perception of service innovation $(\beta=0.24, p<0.05)$. These results revealed that both perceived functional benefit from service providers, and perceived social benefit from service providers are important factors to affecting customers' perception of service innovation.

The results also revealed that perceived functional benefits from service providers had 
a significantly positive effect on customers' participation $(\beta=0.53, \mathrm{p}<0.01)$ which supported H3. Consistent with H4, social benefit from service providers significantly exert a positive effect on customers' participation $(\beta=0.31, \mathrm{p}<0.01)$. These results show that customers' participation was found to be significantly related to customers' perception of service innovation $(\beta=0.28, \mathrm{p}<0.05)$ which H5 was supported.

In order to verify the mediation effect of customer participation in the relationship between customers' perceived functional (social) benefits from service providers, and customers' perception of service innovation, indirect effects were estimated. To verify the effect of mediating variables, testing all the path directly is recommended.(Edelman et al., 2005).

As shown in table 4 , the effect of perceived functional benefits from service providers on perception of service innovation was partially mediated by customers' participation $(\beta=$ $0.12, \mathrm{p}<0.01$ ). In addition, the partial mediation of customers' participation was revealed in the relationship between perceived social benefits from service providers and customers' perception of service innovation $(\beta=0.12, p<0.01)$. Thus, both $\mathrm{H} 6$ and $\mathrm{H} 7$ were all supported.

Table 4 depicts the direct, indirect and total effects of each independent variable on customers'perception of service innovation. The direct, indirect and total effects of customers' perceived functional benefits, and social benefits from service providers on customers'perception of service innovation were found to be significant. As a result, customer participation partially mediated the relationship between customer's perceived functional (social) benefits from service providers and customers'perception of service innovation.

Table 3 : Structural Model Results (Standard regression weights)

\begin{tabular}{|l|c|c|c|c|}
\hline \multirow{2}{*}{ Dependent variables } & \multicolumn{2}{c|}{$\begin{array}{c}\text { Customers' } \\
\text { participation }\end{array}$} & \multicolumn{2}{c|}{$\begin{array}{c}\text { Customers' perception } \\
\text { of service innovation }\end{array}$} \\
\cline { 2 - 5 } & $\beta$ & t-value & $\beta$ & t-value \\
\hline Exogenous variables & & & & \\
Customers' perceived functional benefit & .53 & 4.82 & .29 & 2.18 \\
Customers' perceived social benefit & .31 & 2.86 & .24 & 1.98 \\
\hline Endogenous variable & & & & \\
Customers' participation & .28 & 2.17 & & \\
\hline
\end{tabular}

Table 4 : Effects of Independent Variables on Customers' Perception of Service Innovation

\begin{tabular}{|l|l|l|l|}
\hline Variables & Direct effects & \multicolumn{1}{|c|}{$\begin{array}{c}\text { Indirect } \\
\text { effects }\end{array}$} & Total effects \\
\hline Customers' participation & $.28^{*}$ & & $.28^{*}$ \\
\hline Customers' perceived functional benefits & $.29^{*}$ & $.15^{*}$ & $0.44^{*}$ \\
\hline Customers' perceived social benefits & $.24^{*}$ & $.09^{*}$ & $0.33^{* *}$ \\
\hline
\end{tabular}

Asterisks indicate the level of significance: ${ }^{*}<.05,{ }^{* *}<.01$, 


\author{
IBIMA Publishing \\ Journal of Administrative Sciences and Technology \\ http://www.ibimapublishing.com/journals/JAST/jast.html \\ Vol. 2014(2014), Article ID 130915, 14 pages \\ DOI: $10.5171 / 2014.130915$
}

\section{General Discussion}

Previous studies have focused on manufacturing innovation (Schumpeter, 1934), and service innovation has been evaluated only as a way of increasing productivity (Drejer, 2004). In the past, few studies have been conducted on service innovation success factors (de Brentani and Cooper, 1992). The goal of the present study is to explore the mediating result of customer participation on customers' perception of service innovation, by examining the inter relationships between customers'perceived relational benefits, customers' participation, and customers' perception of service innovation. Customers' relational benefits are divided into functional and social benefits, and the positive effects of these two variables on customers' perception of service innovation are examined. The results show that customers'perceived relational benefits can be the main factors involved in service innovation and in service centers for IT products. Previous studies have indicated that relational benefits have positive effects on customer loyalty and relationship commitment (Palmatier et al, 2006). However, this study is novel from a customer perspective because it shows that perceived relational benefits directly affect service innovation, leading to further expansion of relational benefits. Relational benefits have been introduced and studied from the perspective of companies, but very few studies have explored the customer perspective (Zhu and Kramer, 2002; Su et al., 2009).

Additionally, the way customer participation acts as an intermediary was examined, and customers'perceived relational benefits were found to positively affect customers' perception of service innovation. Thus, it is significant that the relationship between customer participation and service innovation,which has not been clearly empirically proven in previous studies, was identified in the current study. It is necessary to recognize the importance of customer participation in increasing service innovation and to make efforts to prepare for its utilization.

Service-oriented businesses should also increase service benefits that have a direct effect on customer satisfaction in order to enhance service innovation.Service concepts for the IT products industry should be reestablished whenever customer service adjusts to changes in customer expectations, so that service benefits can be improved.

The production and consumption of a service occur concurrently. Thus, the interaction with customer is very important when creating value through service. Customers are important participants in co-creating service value. Further, for service innovation, it is important to build durable bonds with suppliers and other business partners, as well as customers and employees (Bygstad and Lanestedt, 2009). Customer interaction means customer involvement in the service production and delivery process (Zhang, 2007). Although, customer interaction is known to be important for service innovation, few studies examine the importance of customer participation in service innovation. Thus, this paper is significant, asit shows empirically that consumer participation is vital to the service innovation process.

The results of this study on the impact of customer participation on perceived service innovation has theoretical implications; one of the topics in this study on service innovation who play the role of co-creator of service innovation (Alam 2002; Nam and Lee 2010). Meanshile, Jin et al. (2010) reported that active participation in online communities positively affect the member's perceived relational benefits, but this paper shows that the perceived relational benefits gained from service providers in customer service centers will cause increased customer participation, which then leads to the increase of perceived service innovation, thus

Cite this Article as: Wujin Chu and MinjeongKang (2014), " The Effects of Customers' Perceived Relational Benefits on The Customer Perception of Service Innovation at Service Centers for IT Products: The Mediating Role of Customer Participation ", Journal of Administrative Sciences and Technology , Vol 2014 (2014), Article ID 130915, DOI: 10.5171/2014.130915 
differentiating these results from those of existing research papers.As the degree of customer participation is empirically important, customer participation should be increased,and customers should be encouraged to participate in order for company personnel to maintain good relationships with them.

On the other hand, Chesbrough (2011) believesthat manufacturing industries will have to change toward using a service-mind set business model rather than a productoriented business model, so as to remain competitive in the market, and the current study's findings agree with Chesbrough's results in this context; the importance of service innovation in the IT products field and in customer service centers for IT Products were confirmed.

Service innovation is divided into (1) industry level, (2) organization level, (3) customer relationship level, and (4) production level innovation. Among these levels, service innovation at the customer relationship level occurs when a service provider focuses on customers, and each individual customer relationship is an example of innovation at this level. As discussed here, service innovation is limited to the customer relationship level (Coombs and Miles, 2000). Future studies are needed to investigate service innovation at various levels, other than the customer relationship level, and the affecting factors (Reynolds and Beatty, 1999).

Previously, the definitions of service innovation and product innovation were used interchangeably, and research papers were limited to product innovation (de Brentani, 1995) Today, as service innovation gains importance, research papers that concentrate on service are necessary.

\section{Limitations and Future Research}

The factors that affect service innovation are varied. While, the present study considers social and functional benefits, more factors may need to be recognized in future studies.
Additionally, there are few studies on service businesses that draw connections between service benefits and service innovation, and these studies are limited in scope. A range of studies on service innovation will

complement the existing literature. Further, it is necessary to undertakes studies on the effects of service innovation on service performance.

In future studies, a variety of marketing implications should be derived by examining different types of services (for example, ratio of services with high customer participation to services with low customer participation), cultural background, and user characteristics (duration of use, loyalty, types for services, etc). Different customers expect different relational benefits (Gwinner et al., 1998; Su et al., 2009) because they perceive the value of relational benefits differently, based on cultural background or personal factors (Patterson and Smith, 2001). A comparison of these variables, between benefit type and service innovations, may also prove useful.

In the present study, the only services investigated were those provided in customer service centers for IT products. Specifically, the effect of service offerings on service innovation was studied. For generalization of the research model, an empirical analysis is needed, targeting not only IT customer service centers but a range of service areas. Additionally, studies on countries other than Korea are necessary.

This study has some limitations: The service innovation surveys focused only on customers. Thus, future studies need to examine in depth the different dimensions of service innovation, and to evaluate questionnaires from different perspectives. Additionally, as companies demonstrate positive outcomes in service innovation over a period time after they have delivered services, longitudinal research is essential. Lastly, this study showed a sampling bias toward university students. Thus, it would be helpful to obtain samples with different 
demographic characteristics in future studies.

\section{Acknowledgements}

This research was supported by the Institute of Management Research at Seoul National University.

\section{References}

1. Alam, I. (2002),'An Exploratory Investigation of User Involvement in New Service Development,'Journal of the Academy of Marketing Science, 30 (3), 250-61.

2. Anatan, L.andRadhi, F. (2007),'Examining the Moderating Effect of Technology on Manufacturing Strategy and Performance Relationship,'JurnalEkonomidanNisnis Indonesia, UniversitasGradjahMada.

3. Bagozzi, Richard P. and Yi,Youjae (1988),'On the Evaluation of Structural Equation Models,'Journal of the Academy of Marketing Science, 16 (Spring), 74-94.

4. Baker, W.E. andSinkula, J.M. (1999), 'Learning Orientation, Market Orientation and Innovation: Integrating and Extending Models of Organizational Performance,'Journal of Market Focused Management, 4 (4), 295-308.

5. Beatty, S. E., Mayer, M., Coleman, J. E., Reynolds, K. E.and Lee, J. (1996),'CustomerSales Associate Retail Relationships,'Journal of Retailing, 72(3), 223-247.

6. Berry, Leonard L.,Shankar,Venkatesh, Parish, Janet Turner, Cadwallader, Susan andDotzel, Thomas (2006),'Creating New Markets Through Service Innovation,'MIT Sloan Management Review, 47 (2), 56-63.

7. Bettencourt, L.(1997),'Customer Voluntary Performance: Customer as Partners in Service Delivery,'Journal of Retailing, 73 (3), 383-406.

8. Bygstad, B. andLanestedt, G. (2009),'ICT Based Service Innovation - a Challenge for Project Management,'International Journal of Project Management, 27(3), 234-242.
9. Byrne, Barbara (1998),'Structural Equation Modeling with LISREL, PRELIS, and SIMPLIS: Basic applications and programs,' Lawrence Erlbaum, New Jersey.

10. Carman, J. M. andLangeard, E. (1980),'Growth Strategy for Service Firms,'Strategic Management Journal, 1(1), 722.

11. Chan, Kimmy W., Yim, Chi Kin (Bennett) and Lam, Simon K. (2010),'Is Customer Participation in Value Creation a DoubleEdged Sword? Evidence from Professional Financial Services Across Cultures,'Journal of Marketing, 74(3), 48-64.

12. Chesbrough, H. (2011),'Open Services Innovation: Rethinking Your Business to Grow and Compete in a New Era,'Jossey-Bass.

13. Coombs, R.and Miles, I. (2000),Innovation, Measurement and Services: the New Problematique, In Metcalfe, J.S., Miles, I. (Eds.),' Innovation Systems in the Services Economy: Measurement and Case Study Analysis. Kluwer Academic Publishers, Boston, 85-103.

14. Dabholkar, Pratibha (1990),'How to Improve Perceived Service Quality by Improving Customer Participation, in Developments in Marketing Science, B.J.Dunlap (Eds.),' Cullowhee, NC: Academy of Marketing Science, pp 483-487.

15. denHertog, P. (2000),'KnowledgeIntensive Business Services as Co-Producers of Innovation,'International Journal of Innovation Management, 491-528.

16. deBrentani, U.and Cooper, R.G. (1992),'Developing successful new financial services for business,'Industrial Marketing Management,21, 231-241.

17. deBrentani, U. (1995),'New Industrial Service Development: Scenarios for Success and Failure,'Journal of Business Research, 32, 93-103. 
18. Dimitriadis, Sergios (2010),'Testing Perceived RelationalBenefits as Satisfaction and Behavioral Outcomes Drivers,'International Journal of Bank Marketing, 28 (4), 297-313.

19. Dotzel, Thomas, Shankar,Venkateshand Berry, Leonard L. (2013),'Service Innovativeness and Firm Value,'Journal of Marketing Research, vol. L. (April), 259-276.

20. Drejer, I. (2004),'Identifying Innovation in Surveys of Services: A Schumpeterian Perspective,'Research Policy, 33 (3), 551-562.

21. Edelman, L. F., Brush, C.G., Manolva, T. (2005),'Co-alignment in the ResourcePerformance Relationship: Strategy as Mediator,'Journal of Business Venturing, 20, 359-383.

22. Edvardsson, B., Gustafsson, A. andRoos, I. (2004),'Service Portrays and Service Constructions - A Critical Review through the Lens of the Customer,'International Journal of Service Industry Management, 16 (1), 107121.

23. Eisingerich, Andreas B. and Bell, Simon J. (2006),'Analysis Papers Relationship marketing in the Financial Services Industry: The Importance of Customer Education, Participation and Problem Management for Customer Loyalty,'Journal of Financial Services Marketing, 10, 486-97.

24. Fornell, C. andLarcker, D. F. (1981),'Evaluating Structural Equation Models with Observable Variables and Measurement Error,'Journal of Marketing Research, 18 (1), 39-50.

25. Gwinner, K. P., Gremler, D. D. andBitner, M. J. (1998),'Relational Benefits in Services Industries: The Customer's Perspective,'Journal of the Academy of Marketing Science, 26 (2), 101-114.

26. Hair, J.F., Anderson, R.E., Tatham, R.L., and Black, W.C. (1998),'Multivariate Data Analysis (5th ed.), New Jersey: Prentice-Hall International.

27. Hair, J. F. Jr. Black, W. C., Babin, B. J. Anderson, R. E. andTatham, R. L. (2006),'Multivariate data analysis,' 6th ed. New Jersey: Prentice Hall.

28. Hakansson, H. and Ford, D. (2002),'How Should Companies Interact in BusinessEnvironments,'Journal of Business Research, 55, 133-139.

29. Hipp, C. andGrupp, H. (2005),'Innovation in the Service Sector: The Demand for Service-specific Innovation Measurement Concepts and Typologies,'Res. Policy, 34, 517535.

30. Jackson, Barbara Bund. (1985),'Building Customer Relationships that Last,'Harvard Business Review, 63, 120-128.

31. Jin, Byungho, Park, Jin Yong and Kim, Hye-Shin (2010),'What Makes Online Community Members Commit? A Social Exchange Perspective, Behaviourand Information Technology, 29 (6), 587-599.

32. Kim, In Soo (2012),'Hotel Food Service : The Effects of Service Innovation, Performance on Market Orientation in the Hotel Industry; Focusing on 5 star hotels in Seoul,'Journal of Hospitality and Tourism Studies, 14 (44), 113-126.

33. Kuusisto, A. andRiepula, M. (2011),'Customer Interaction in Service Innovation: Seldom Intensive but often Decisive. Case Studies in three Business Service Sectors,'Int. J. Technology Management, 55 (1/2), 171-186.

34. Liu, X. L. and Chen, X. G. (2007),'Service Innovation Mechanism based on CustomerEmployee Interaction, International Conference on Management Science and Engineering, 2007.

35. Lovelock, C. H., Patterson, P. G.and Walker, R. H. (2001),'Services Marketing: An AsiaPacific Perspective 2nd Ed,' Australia: Prentice 
Hall.

36. McAdams, D., Hart, H., andMaruna, S. (1998),'The Anatomy of Generativity. In D. McAdams and E. St. Aubin (Eds.),'Generativity and Adult Development. How and Why We Care for the Next Generation. Washington, DC: American Psychological Association.

37. McLaughlin, S. and Paton, R. A. (2008),'Identifying Barriers thatImpact Knowledge Creation and Transfer within Complex Organisations,'Journal of Knowledge Management, 12(4).

38. Menor, L., Tatikonda, M. and Sampson, S. (2002),'New Service Development: Areas for Exploitation and Exploration,'Journal of Operations Management, 20 (2), 135-157.

39. Morgan,Robert M.and Shelby D. Hunt (1994), 'The Commitment-Trust Theory of Relationship Marketing.'Journal of Marketing, 58 (July), 20-38.

40. Nam, K.and Lee, N. H. (2010), 'Typology of Service Innovation from Service-Dominant Logic Perspective,'Journal of Universal Computer Science, 16 (13), 1761-1775.

41. Palmatier, Robert

W., Gopalakrishna,Srinathand Houston, Mark B. (2006),'Returns on Business-to-Business Relationship Marketing Investments:Strategies for Leveraging Profits,'Marketing Science, 25, 477-93.

42. Patterson, P.G. and Smith, T. (2001),'Relationship Benefits in Service Industries: A replication in a Southeast Asian Context,'Journal of Services Marketing, 15(6), 425-443.

43. Prahalad, C. K. andVenkatramRamaswamy (2000),'Co-Opting Customer Competence,'Harvard Business Review, 78(Feb), 79-87.

44. Price, Linda L. andAmould, Eric J. (1999),'Commercial Friendships: Service
Provider-Client Relationships in Social Context,'Journal of Marketing, 63 (October), 38-56.

45. Reynolds, T. J.andGutman, J. (1984), 'Advertising is Image Management,'Journal of Advertising Research, 24(1), 27-37.

46. Reynolds, K. E.and Beatty, S. E. (1999),'Customer Benefits and Company Consequences of Customer-Salesperson Relationships in Retailing,'Journal of Retailing, 75 (1), 11-32.

47. Rodie, A. R. andKleine, S. S. (2000),'Customer Participation in Services Production and Delivery, In T. A. Swartz, and D. Iacobucci (Eds.),' Handbook of Services Marketing and Management: 111-125. Thousand Oaks: Sage Publications.

48. Schumpeter, J.A. (1934),'The Theory of Economic Development,'Harvard Press, Cambridge,MA.

49. Schwarz, Sven, Durst CarolinandBodendorf, Freimut (2012),'Service Innovation : A Roadmap for Practitioners,'Service Science and Management Research (SSMR), 1 (1), 12-16.

50. Silpakit, P. and Fisk, R.P. (1985),'Participating the Service Encounter: a Theoretical Framework, In Block, T.M., Upah, G.D. and Zeithaml , V.A.(Eds.),'Service Marketing in a Changing Environment, American Marketing Association ,Chicago , IL, 117-121.

51. Singhi, Rushinaand Agarwal, Swati (2011),'Information Technology Drives Innovation in Service Customers' Perspective,'Amity Management Review, 2 (1), 34-38

52. Storey, C. andEasingwood, C.J. (1993),'The Impact of the New Product Development Project on Financial Service Success,'Service Industries Journal, 13 (3), pp 40-54.

53. Su,Qin, Li, LingandCu, Yan $\mathrm{Wu}$ (2009),'Analyzing Relational Benefits in E- 
business Environment from Behavioral Perspective,'Systems Research and Behavioral Science, 26 (2),129-142.

54. Sundbo, J. (1997),'Management of Innovation in Services,'The Service Industries Journal, 17 (3), 432-455.

55. Sweeney, Jillian C. and Webb, Dave (2007),'How Functional, Psychological and Social Relationship Benefits Influence Individual and Firm Commitment To The Relationship,'Journal of Business and Industrial Marketing, 22(7), 474-488.

56. Toivonen, M. andTuominen, T. (2009),Emergence of Innovations in Services,'Service Industries Journal, 29(7), 887-902.

57. Turner, W. L. andReisinger, Y. (2001),'Shopping Satisfaction for Domestic Tourists,'Journal of Retailing and Consumer Services, 8 (1), 15-27.

58. van Riel, Allard C. R., Lemmink, Jos andOuwersloot, Hans (2004),'HighTechnology Service Innovation Success: A Decision-Making Perspective,'Journal of Product Innovation Management, 21, 348359.

59. Vargo, Stephen L. andLusch, Robert F. (2004),'Evolving to a New DominantLogic for
Marketing,'Journal of Marketing, 68 (January), 1-17.

60. Wu, Cedric His-Jui (2011),'A Reexamination of the Antecedents and Impact of Customer Participation in Service,'The Service Industries Journal, 31 (6), 863-876.

61. Xin Y., Chai K.H. and Tan, K.C. (2006),'Service Innovation: Review and Future ResearchAreas,'Proceedings of IEEE International Conference on Management of Innovation andTechnology, 21-23 June, Singapore, 309-314.

62. Yoon, M. H., Sea, J. H. and Yoon, T.S. (2004),'Effects of Contact Employee Supports on Critical Employee Responses and Customer Service Evaluation,'Journal of Consumer Research, 18(5), 395-412.

63. Zhang Ruo-yong; Lin, Xin-meiandLiu, Dewen (2007),'Customer Knowledge Transfer and Service Innovation Performance: A Customer-firm Interaction Perspective,'Service Systems and Service Management, 2007 International Conference

64. Zhu, K.and Kraemer, K. L. (2002),'Ecommerce Metrics for NetenhancedOrganizations: Assessing the Value of E-commerce to FirmPerformance in the Manufacturing Sector,'Inform. Systems Res,13(3), 275-295. 